\title{
Submitted: Iodinated contrast-induced sialadenitis: a review 11.04 .2018 Accepted: of the literature and sonographic findings in a clinical case
}

13.07.2018

Published:

31.12 .2018

\author{
Antonio Lucarelli, Simone Perandini, Alessandro Borsato, \\ Endrit Strazimiri, Stefania Montemezzi
}

Department of Radiology, University Hospital of Verona, Polo Chirurgico "Confortini”, Verona, Italy

Correspondence: Antonio Lucarelli, Department of Radiology, University Hospital of Verona, Polo Chirurgico "Confortini”,Verona, Italy; e-mail: antoneello@gmail.com

DOI: $10.15557 / J o U .2018 .0053$

\section{Keywords \\ iodine, mumps,}

contrast media, ultrasound imaging

\begin{abstract}
Swelling of the salivary glands, also known as iodide or iodine mumps, is a rare adverse reaction to administration of iodine, a component steadily present in current contrast media and in a variety of medications. We report and compare with published literature the clinical and sonographic findings in a case of iodide mumps that developed after the intravenous administration of iodine-based contrast media for a contrast-enhanced computed tomography scan. The exact pathogenesis is unknown to date: based on sonographic appearance, we support the hypothesis of an acute inflammatory condition elicited by iodine accumulation in the salivary glands. The emergency care practitioner needs to be confident with the clinical symptoms as well as the sonographic findings and therapeutic options to successfully manage this condition.
\end{abstract}

\section{Introduction}

Swelling of the salivary glands following the administration of iodine-containing contrast media, known as "iodide mumps", is a rare adverse reaction.

The first reported case of contrast-related sialadenitis was described by Sussman and Miller in 1956 and occurred after intravenous urography ${ }^{(1)}$. Since this description, there have been approximately 50 cases of iodide mumps reported in the literature.

The condition is thought to represent a response to iodine accumulation in the salivary glands, but no clear etiology has been determined to date.

A review (1992) of package inserts for contrast material from four major pharmaceutical manufacturers in the United States (Squibb, Benlex, Mallinckrodt, Winthrop) showed that only one company (Winthrop) mentioned swelling of salivary glands as a possible adverse reaction to iodinated contrast agents ${ }^{(2)}$.

A personal review of other three major contrast media manufacturers, also operating in the European Union
(General Electrics Healthcare, Bracco Imaging, Bayer), showed that all companies mentioned salivary gland swelling as a possible adverse reaction.

The rarity of the occurrence of this condition may hinder prompt diagnosis and appropriate treatment. Furthermore, because of the widespread use of iodinated contrastenhanced imaging, such as computed tomography (CT), and interventional techniques, clinicians should be aware of this entity.

We report a case of iodide mumps that developed after the administration of iodine-based contrast media during a CT examination, by describing and illustrating clinical and sonographic findings, along with a review of the relevant literature.

\section{Case report}

A 68-year-old Caucasian woman was referred for a chest CT scan because of irritating cough. The patient had a history of 8 years of high blood pressure, with a peak systolic blood pressure of $170 \mathrm{~mm} \mathrm{Hg}$, under control with $150 \mathrm{mg}$ of Irbesartan once per day (Aprovel, $150 \mathrm{mg}$, Sanofi-Aventis, Switzerland). Her kidney function was normal (serum creatinine 




Fig. 1. Submandibular swelling the day after the onset

level: $0.59 \mathrm{mg} / \mathrm{dL}$ ). A history of smoking (1 pack/day) and allergy to aspirin, penicillin and erythromycin were present. She had never received iodide-containing contrast.

CT was performed after high-flow $(3 \mathrm{~mL} / \mathrm{sec})$ intravenous injection of $70 \mathrm{~mL}$ of low osmolality contrast agent (Iohexol, Omnipaque 350). The examination was completed uneventfully, and the patient left the scanning room with no symptoms.

A review of the $\mathrm{CT}$ images revealed the presence of a spiculated lung mass with a central solid component measuring approximately $30 \times 20 \mathrm{~mm}$ and showing intense contrast enhancement, consistent with invasive adenocarcinoma.

About 12 hours later, she arrived at the Emergency Department complaining about painless bilateral neck swelling.
Physical examination revealed tender enlargement of the submandibular areas, seemingly related to the submandibular glands. The overlying skin was intact (Fig. 1).

There was no evidence of laryngeal edema or bronchospasm.

Routine laboratory tests were prescribed and were found to be unremarkable.

A sonographic evaluation of the salivary glands and cervical region was recommended.

Ultrasound of the neck was performed with a high-frequency linear transducer $(12 \mathrm{MHz})$ on a high-grade ultrasound machine (HD15, Koninklijke Philips BV, Eindhoven, Netherlands) from an expert sonographer (more than 15 years of service).

Gray-scale ultrasound showed significant and symmetrical swelling of both submandibular glands which had a long axis of more than $3 \mathrm{~cm}$ and featured internal hypoechoic tubular structures (that most likely represented dilated ducts), without any appearance of sialoliths (Fig. 2).

Additionally, a few inflamed lymph nodes were visualized around the glands, appearing as oval hypoechoic lesions with a hyperechoic central area.

The submandibular glands also appeared surrounded by a thin layer of peripheral fluid collection. The parotid and thyroid glands were not swollen and had a normal appearance.

Color-Doppler ultrasound showed a moderate increase in vascularity, particularly in the central part of the submandibular glands (Fig. 3).

As a first-line strategy, steroid therapy was prescribed, in the form of 1 tablet/day of prednisone acetate (Deltacortene, 25 mg tablets, Bruno Farmaceutici SpA, Roma, Italy) for 4 days. However, the patient continued to com-
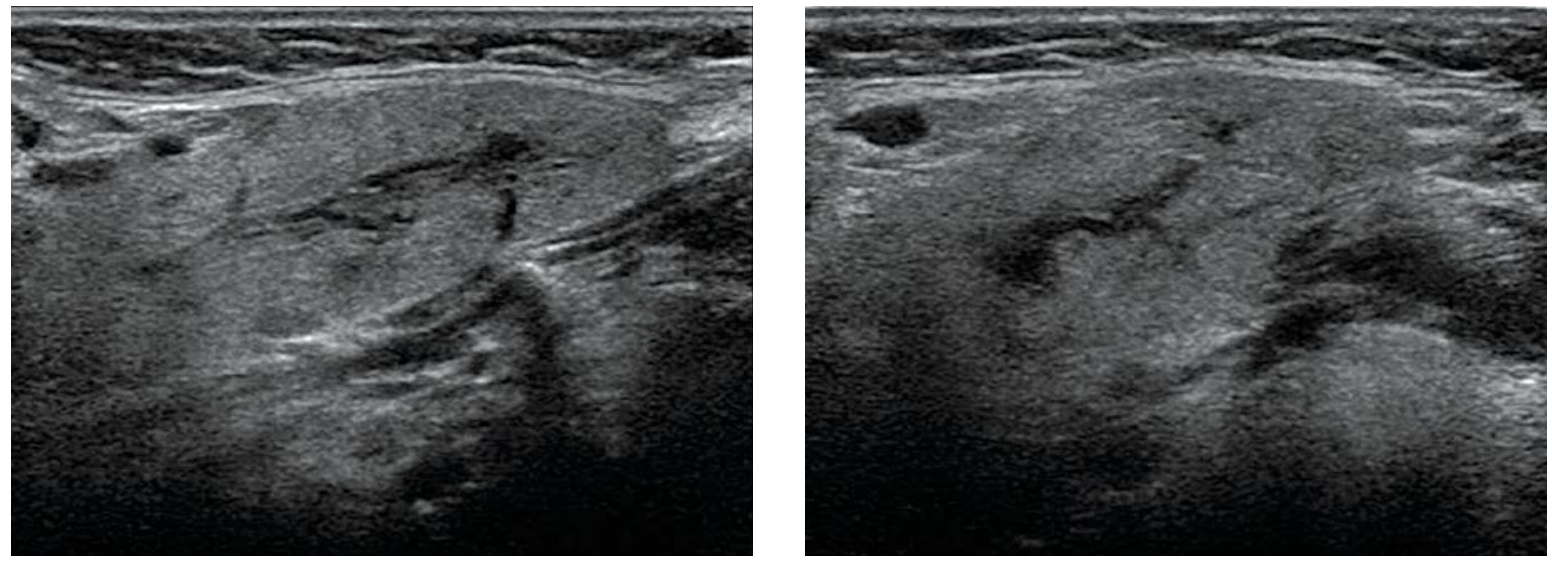

Fig. 2. Ultrasound images of the submandibular glands, showing internal hypoechoic tubular structures without any appearance of sialoliths 

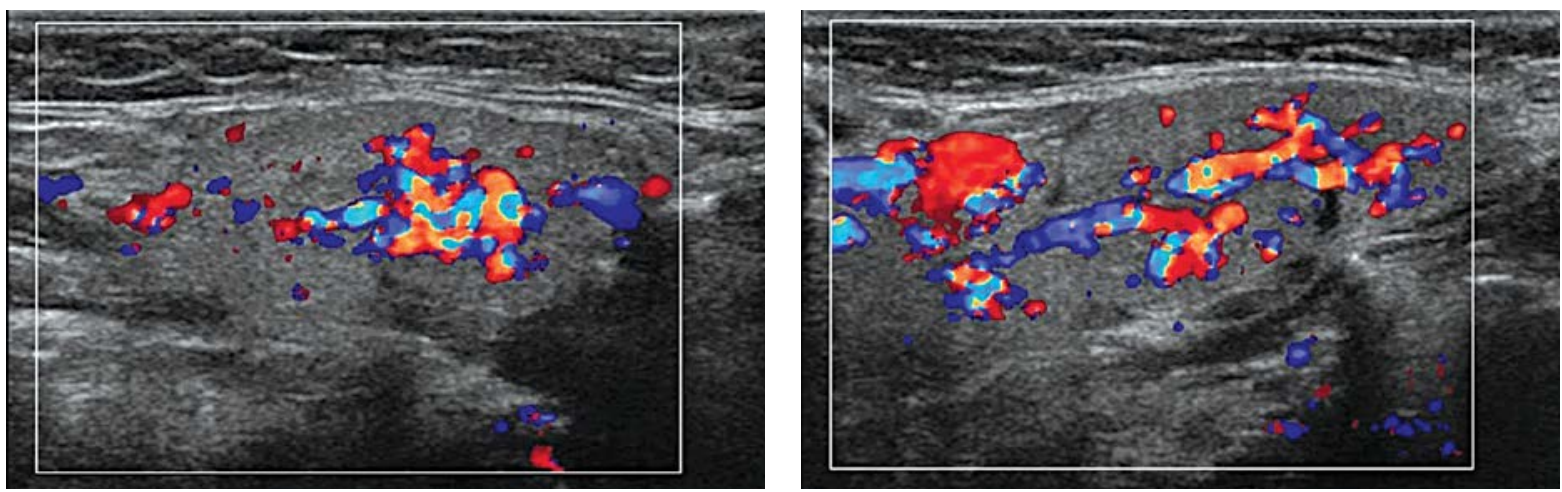

Fig. 3. Doppler images of the submandibular glands revealing parenchyma hypervascularity, which is more prominent in the central region of the glands

plain about swelling during therapy. Only 7 days after the onset, the swelling started to regress (Fig. 4). The submandibular glands returned to the normal size and echo-structure within 10 days, with complete normalization of the sonographic appearance at a repeat ultrasound scan at 14 days.

\section{Discussion}

Iodide mumps is a rare adverse reaction to iodine-containing contrast media administration, characterized by a rapid, usually painless enlargement of salivary glands.

Approximately 50 cases of iodide mumps have been reported in literature to date; 37 were summarized by Zhang

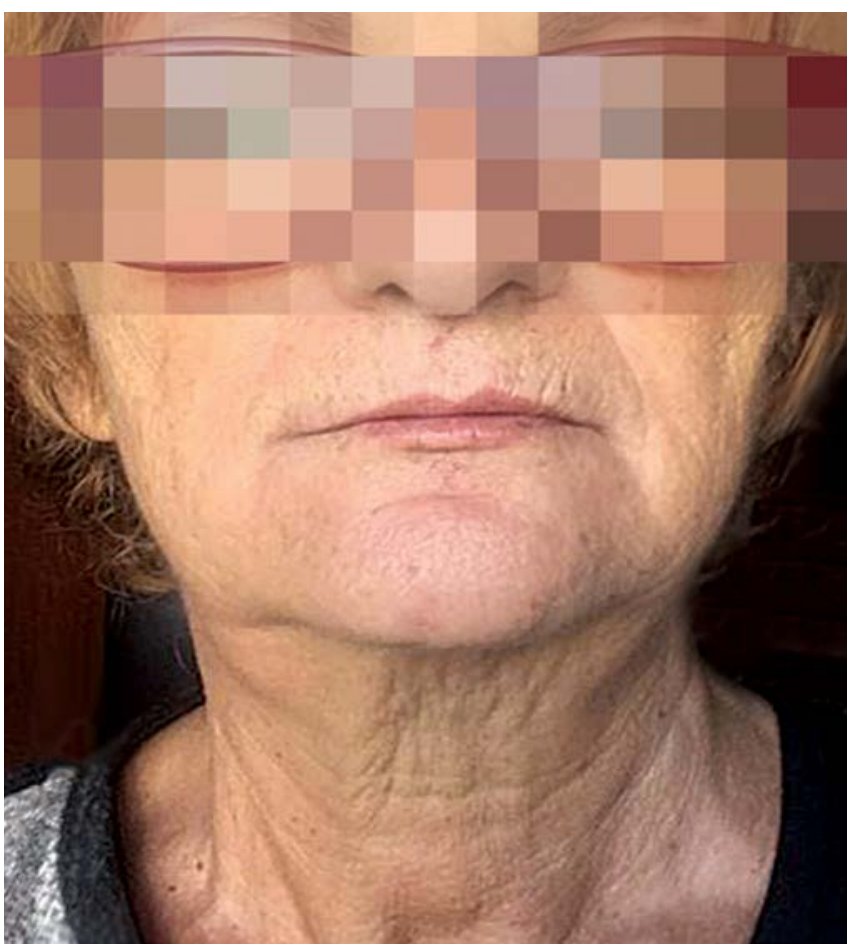

Fig. 4. Appearance of the neck after 7 days from the onset in a previous review ${ }^{(3)}$, and the newest cases are reported in Tab. 1.

Iodide mumps have been described in patients of all ages, with no clear predilection of sex or ethnicity. Of the 52 cases of iodide mumps identified in literature, 31 men and 21 women were affected, ranging from 8 to 80 years, from Asiatic, European and American countries.

A defined pathogenesis of this condition must be established to date, with many authors suggesting different associations, such as kidney failure. It is thought that nearly $98 \%$ of administered iodide is eliminated by the kidneys and the remaining $2 \%$ is secreted from salivary and lacrimal glands, sweat and other organs; as a result, renal impairment may represent a facilitating factor, potentially leading to increased salivary gland secretion and accumulation. As a matter of fact, 17 out the 52 cases had a diagnosis of renal impairment.

The description of cases of iodide mumps in patients without renal failure supports different pathogenetic mechanisms, too.

An overt allergic reaction was ruled out by the lack of specific symptoms such as rash, angioedema, dyspnea and hypotension. Furthermore, anaphylactic reactions usually occur within 30 minutes after exposure and need prior sensitization to the antigen; on the other hand, iodide mumps are reported to occur as a delayed reaction to first exposure to iodinated contrast media.

One possible mechanism is a non-inflammatory condition of the salivary glands, also known as sialosis. This condition usually coexists with metabolic, endocrine or autonomic disorders and can be triggered using certain drugs, such as diuretics ${ }^{(14)}$. In sialosis, the submandibular glands have been described in sonography as hyperechogenic, enlarged and with no associated hyperemia, which was ruled out in Doppler imaging.

On the other hand, some authors have reported imaging findings of iodide mumps which are consistent with a diagnosis of acute sialadenitis, in which submandibular glands usually appear enlarged, with heterogeneous and 


\begin{tabular}{|c|c|c|c|c|c|c|c|c|}
\hline Author, year & $\begin{array}{c}\text { Age } \\
\text { (years)/ } \\
\text { sex }\end{array}$ & $\begin{array}{l}\text { Renal } \\
\text { disease }\end{array}$ & Onset & Type of contrast & $\begin{array}{c}\text { Route of } \\
\text { administration }\end{array}$ & $\begin{array}{l}\text { Glands } \\
\text { involved }\end{array}$ & $\begin{array}{l}\text { Dura- } \\
\text { tion }\end{array}$ & $\begin{array}{l}\text { Other clinical } \\
\text { features }\end{array}$ \\
\hline $\begin{array}{l}\text { Panasoff J et al., } \\
2008^{(4)}\end{array}$ & $70 / \mathrm{M}$ & Nil & $6 \mathrm{~h}$ & $\begin{array}{l}\text { Nonionic contrast } \\
\text { (lopromide, } 100 \mathrm{~mL} \text { ) }\end{array}$ & $\begin{array}{c}\text { Intravenous } \\
\text { injection } \\
\text { (enhanced CT scan) }\end{array}$ & $\begin{array}{l}\text { Bilateral, } \\
\text { Parotid }\end{array}$ & $5 d$ & Nil \\
\hline $\begin{array}{l}\text { Panasoff J et al., } \\
2008^{(4)}\end{array}$ & $51 / \mathrm{M}$ & Nil & $1 d$ & $\begin{array}{l}\text { Nonionic contrast } \\
\text { (lopamidol) }\end{array}$ & $\begin{array}{c}\text { Intravenous } \\
\text { injection } \\
\text { (enhancedCTscan) }\end{array}$ & $\begin{array}{l}\text { Bilateral, } \\
\text { Parotid }\end{array}$ & $14 d$ & $\begin{array}{l}\text { Urticaria and } \\
\text { dizziness } \\
\text { immediately } \\
\text { after injection }\end{array}$ \\
\hline $\begin{array}{l}\text { Federici M et al., } \\
2008^{(5)}\end{array}$ & $77 / F$ & Nil & $18 \mathrm{~h}$ & $\begin{array}{l}\text { Nonionic contrast } \\
\text { (lopromide, } 120 \mathrm{~mL} \text { ) }\end{array}$ & $\begin{array}{c}\text { Intravenous } \\
\text { injection } \\
\text { (enhanced CT scan) }\end{array}$ & $\begin{array}{c}\text { Bilateral, } \\
\text { Submandibular }\end{array}$ & $2 d$ & Nil \\
\hline $\begin{array}{l}\text { Greco S et al., } \\
2010^{(6)}\end{array}$ & 38/M & Nil & $18 \mathrm{~h}$ & $\begin{array}{l}\text { Nonionic contrast } \\
\text { (lopromide, } 120 \mathrm{~mL} \text { ) }\end{array}$ & $\begin{array}{c}\text { Intravenous } \\
\text { injection } \\
\text { (enhanced CT scan) }\end{array}$ & $\begin{array}{c}\text { Bilateral, } \\
\text { Submandibular }\end{array}$ & $2 d$ & Painful \\
\hline $\begin{array}{l}\text { Sajeev CG et al., } \\
2013^{(7)}\end{array}$ & 70/M & Nil & $10 \mathrm{~h}$ & $\begin{array}{l}\text { Nonionic contrast } \\
\text { (lopromide, } 50 \mathrm{~mL} \text { ) }\end{array}$ & $\begin{array}{c}\text { Artery } \\
\text { angiography }\end{array}$ & $\begin{array}{l}\text { Bilateral, } \\
\text { Submandibular, } \\
\text { Parotid }\end{array}$ & $5 d$ & Nil \\
\hline $\begin{array}{l}\text { Jain R et al., } \\
2013^{(8)}\end{array}$ & $80 / F$ & Nil & $15 \mathrm{~h}$ & $\begin{array}{l}\text { Nonionic contrast } \\
\text { (lopromide, } 150 \mathrm{~mL} \text { ) }\end{array}$ & $\begin{array}{c}\text { Artery } \\
\text { angioplasty }\end{array}$ & $\begin{array}{l}\text { Bilateral, } \\
\text { Parotid }\end{array}$ & $3 d$ & Nil \\
\hline $\begin{array}{l}\text { Fok JS et al., } \\
2014^{(9)}\end{array}$ & 78/M & $\begin{array}{l}\text { Renal } \\
\text { failure }\end{array}$ & $16 \mathrm{~h}$ & $\begin{array}{l}\text { Nonionic contrast } \\
\text { (lopromide, } 100 \mathrm{~mL} \text { ) }\end{array}$ & $\begin{array}{l}\text { Intravenous } \\
\text { injection } \\
\text { (enhanced CT } \\
\text { scan) }\end{array}$ & $\begin{array}{l}\text { Bilateral, } \\
\text { Submandibular, } \\
\text { Parotid }\end{array}$ & $2 d$ & $\begin{array}{c}\text { Fever }\left(38.2^{\circ} \mathrm{C}\right) \text {, } \\
\text { painful neu- } \\
\text { trophilic cuta- } \\
\text { neous nodules } \\
\text { (Sweet syn- } \\
\text { drome) }\end{array}$ \\
\hline $\begin{array}{l}\text { Khoury TR, } \\
2014^{(10)}\end{array}$ & $65 / M$ & Nil & $12 \mathrm{~h}$ & $\begin{array}{l}\text { lodinated contrast } \\
\qquad(120 \mathrm{~mL})\end{array}$ & $\begin{array}{l}\text { Trans-arterial } \\
\text { chemoemboliza- } \\
\text { tion procedure }\end{array}$ & $\begin{array}{c}\text { Bilateral, } \\
\text { Submandibular }\end{array}$ & $14 d$ & Nil \\
\hline $\begin{array}{l}\text { Egan M et al., } \\
2015^{(11)}\end{array}$ & $76 / F$ & Nil & $12 \mathrm{~h}$ & $\begin{array}{l}\text { Nonionic contrast } \\
\text { (lopamidol, } 150 \mathrm{~mL} \text { ) }\end{array}$ & $\begin{array}{c}\text { Artery } \\
\text { angioplasty }\end{array}$ & $\begin{array}{c}\text { Bilateral, } \\
\text { Submandibular }\end{array}$ & $4 d$ & Nil \\
\hline $\begin{array}{l}\text { Ghosh RK et al., } \\
2015^{(12)}\end{array}$ & $65 / F$ & $\begin{array}{l}\text { Renal } \\
\text { failure }\end{array}$ & $1 d$ & $\begin{array}{l}\text { Nonionic contrast } \\
\text { (lodixanol, } 15 \mathrm{~mL} \text { ) }\end{array}$ & Fistulogram & $\begin{array}{c}\text { Bilateral, } \\
\text { Submandibular }\end{array}$ & $3 d$ & Painful \\
\hline $\begin{array}{l}\text { Elder AM et al., } \\
2016^{(13)}\end{array}$ & $67 / F$ & $\begin{array}{l}\text { Renal } \\
\text { failure }\end{array}$ & $15 \mathrm{~h}$ & $\begin{array}{l}\text { Nonionic contrast } \\
\text { (lopamidol, } 240 \mathrm{~mL} \text { ) }\end{array}$ & $\begin{array}{c}\text { Artery } \\
\text { angiography }\end{array}$ & $\begin{array}{c}\text { Bilateral, } \\
\text { Submandibular }\end{array}$ & $3 d$ & $\begin{array}{l}\text { Neck swelling, } \\
\text { dysphagia }\end{array}$ \\
\hline $\begin{array}{l}\text { Afshar M et al., } \\
2017^{(14)}\end{array}$ & 67/M & $\begin{array}{l}\text { Renal } \\
\text { failure }\end{array}$ & $8 \mathrm{~h}$ & Not mentioned & $\begin{array}{c}\text { Artery } \\
\text { angiography }\end{array}$ & $\begin{array}{c}\text { Bilateral, } \\
\text { Submandibular }\end{array}$ & $5 d$ & $\begin{array}{l}\text { Dysphagia, } \\
\text { hoarseness }\end{array}$ \\
\hline $\begin{array}{l}\text { Zhang G et al., } \\
2017^{(15)}\end{array}$ & $66 / M$ & Nil & $5 \mathrm{~h}$ & $\begin{array}{l}\text { Nonionic contrast } \\
\text { (lodixanol, } 130 \mathrm{~mL} \text { ) }\end{array}$ & $\begin{array}{l}\text { Digital subtrac- } \\
\text { tion angiography }\end{array}$ & $\begin{array}{l}\text { Bilateral, } \\
\text { Parotid }\end{array}$ & $4 d$ & Nil \\
\hline $\begin{array}{l}\text { Current case, } \\
2017\end{array}$ & $68 / F$ & Nil & $12 \mathrm{~h}$ & $\begin{array}{l}\text { Nonionic contrast } \\
\text { (lohexol } 350,70 \mathrm{~mL} \text { ) }\end{array}$ & $\begin{array}{c}\text { Intravenous } \\
\text { injection } \\
\text { (enhancedCT scan) }\end{array}$ & $\begin{array}{c}\text { Bilateral, } \\
\text { Submandibular }\end{array}$ & $10 d$ & Nil \\
\hline $\begin{array}{l}\text { Londrino } \mathrm{F} \text { et al., } \\
2018^{(16)}\end{array}$ & $62 / F$ & $\begin{array}{l}\text { Renal } \\
\text { failure }\end{array}$ & $1 d$ & $\begin{array}{l}\text { lodinated contrast } \\
\quad(130 \mathrm{~mL})\end{array}$ & $\begin{array}{c}\text { Intravenous } \\
\text { injection } \\
\text { (enhancedCTscan) }\end{array}$ & $\begin{array}{c}\text { Bilateral, } \\
\text { Submandibular }\end{array}$ & $3 d$ & Mildly painful \\
\hline $\begin{array}{l}\text { Londrino } \mathrm{F} \text { et al., } \\
2018^{(16)}\end{array}$ & $52 / \mathrm{M}$ & $\begin{array}{l}\text { Renal } \\
\text { failure }\end{array}$ & $1 d$ & $\begin{array}{l}\text { lodinated contrast } \\
\qquad(250 \mathrm{~mL})\end{array}$ & $\begin{array}{c}\text { Artery } \\
\text { angiography }\end{array}$ & $\begin{array}{c}\text { Bilateral, } \\
\text { Submandibular }\end{array}$ & $4 d$ & Nil \\
\hline
\end{tabular}

Tab. 1. Reported cases of the condition since the publication of Zhang (2015) ${ }^{3}$ 
increased echogenicity and with Doppler demonstrating hyperemia (especially in the acute phase). Particularly, of the four sonographic descriptions of iodide mumps available in the available scientific literature, three include the presence of central hyperemia in Doppler imaging ${ }^{(5,6,16)}$. In addition, Zhang found that, in computed tomography, the average density of the affected submandibular glands was lower than normal (20-40 HU), supporting the presence of edema $^{(3)}$. Notably, the only case report of iodide mumps in which a histologic sample was available supported this by describing a "non-inflammatory edema" of the gland parenchyma, probably of vasogenic nature ${ }^{(15,17)}$.

In the presented case, the submandibular glands appeared enlarged, with an inhomogeneous mildly hyperechoic echostructure, surrounded by some lymph nodes and by a thin layer of peripheral fluid collection. Evident hyperemia was also noted in Doppler imaging. Furthermore, the submandibular glands featured internal hypoechoic tubular structures, thought to be dilated ducts, in the absence of sialolithiasis. This may be due to iodine accumulation in salivary secretions, leading to mucosal edema, ductal obstruction and upstream dilatation and subsequent sialadenitis.

Considering all these signs and imaging findings, an acute inflammatory condition of the salivary glands is still the authors' best pathogenetic hypothesis.

Iodide mumps have been reported following the administration of a variety of iodinated contrast agents, including both ionic (18 cases) and nonionic media (27 cases). It has also been demonstrated that the condition can arise independently of the route of administration: of these 52 patients, 26 received intravenous injections, 21 underwent arteriography, 4 ingested an iodide containing compound, and a single case was exposed to both oral and intravenous iodine contrast media. Besides, of note is the fact that iodide mumps have been reported also after the exposure to iodide salts, suggesting a reaction to iodine itself as opposed to its molecular carrier ${ }^{(17)}$.

In the presented case, $70 \mathrm{~mL}$ of low-osmolality contrast agent (Iohexol, Omnipaque 350) was injected intravenously. Iohexol is a non-ionic, monomeric, tri-iodinated, water-soluble contrast medium; its osmolality ranges from $322 \mathrm{mOsm} /$ $\mathrm{kg}$ to $844 \mathrm{mOsm} / \mathrm{kg}$, (almost 3 times that of blood). Despite this, it is still considered a low-osmolality contrast medium compared to older agents. Neither Iohexol nor its excipients (trometamol, sodium calcium edetate, hydrochloric acid) have known interactions with patient's medications.

The reported time of the onset varied from several minutes to 5 days (mean, $1.12 \pm 1.14$ days) after contrast medium administration, corroborating the hypothesis of a delayed adverse reaction.

In the presented case series, iodide mumps more often occurred bilaterally $(47,90.4 \%)$ than unilaterally $(5,9.6 \%)$. The most prominent clinical finding was gland enlargement, with the largest mass reported to be up to approximately $5 \mathrm{~cm}$ in diameter. Tenderness was uncommon, with only 11 out of 52 cases complaining about pain. Twentynine cases involved the submandibular glands, and fifteen cases involved also the parotid glands. This can be supported by the observation that the submandibular glands have a more viscous, prominently mucin-rich, secretion. Occasionally, the involvement of other glands was reported (thyroid, lacrimal gland and pancreas). Facial nerve palsy, erythematous dermatitis and allergic vasculitis are some of the other associated adverse reactions reported with iodinated contrast media ${ }^{(5)}$.

The prognosis of iodide mumps is benign. There have been no reported life-threatening complications of the condition to date. Clinical features persisted for 4 hours to 14 days (mean, $4.22 \pm 3.3$ days) in 50 of the cases, leading to complete healing without sequelae.

Current treatment for iodide mumps is supportive therapy and administration of anti-in ammatory agents, although the role of steroids has been found to be controversial ${ }^{(18)}$. Use of bailout hemodialysis has been proposed to reduce blood levels of iodide in unresponsive patients ${ }^{(19)}$.

It has been reported how repeated exposure to iodinated contrast media could induce iodide mumps in susceptible patients. Nine cases experienced recurrence of the condition also after administration of different forms of low-osmolarity non-ionic iodinated contrast media, proving that the reaction is probably a class effect.

Premedication with antihistamines and corticosteroids was not proven to be beneficial ${ }^{(17)}$.

In conclusion, in clinical practice, the benign course of this syndrome should not limit the use of iodine-based contrast media when it is necessary for diagnostic and therapeutic procedures. At the same time, clinicians must be aware of this event, to avoid more aggressive diagnostic workup.

\section{Conflict of interest}

The authors do not report any financial or personal connections with other persons or organizations, which might negatively affect the content of this publication and/or claim authorship rights to this publication.

\section{References}

1. Sussman RM, Miller J: Iodide mumps after urography. N Engl J Med 1956; 255: 433-434.

2. Berman HL, Delaney V: Iodide mumps due to low-osmolality contrast material. AJR Am J Roentgenol 1992; 159: 1099-1100.
3. Zhang G, Li Y, Zhang R, Guo Y, Ma Z, Wang H et al.: Acute Submandibular Swelling Complicating Arteriography With Iodide Contrast: A Case Report and Literature Review. Medicine (Baltimore) 2015; 94: e1380.

4. Panasoff J, Nusem D: Iodide mumps. World Allergy Organ J 2008; 1: 85-86. 
5. Federici M, Guarna T, Manzi M, Della Longa G, Di Renzi P, Bellelli A: Swelling of the submandibular glands after administration of low-osmolarity contrast agent: Ultrasound findings. J Ultrasound 2008; 11: $85-88$.

6. Greco S, Centenaro R, Lavecchia G, Rossi F: Iodide mumps: sonographic appearance. J Clin Ultrasound 2010; 38: 438-439.

7. Sajeev CG, Mohanan S, Gopalakrishnapillai A, Muneer K: A rare complication of coronary angiography: 'iodide mumps'. Heart 2013; 99: 1222.

8. Jain R, Kanjirakadavath B, Krishnan MN: Contrast-induced acute sialadenitis: iodide mumps. Heart Asia 2013; 5: 126.

9. Fok JS, Ramachandran T, Berce M, Smith WB: Radiocontrast-induced iodide sialadenopathy and neutrophilic dermatosis. Ann Allergy Asthma Immunol 2014; 112: 267-268.

10. Khoury TR: Iodide mumps after trans-arterial chemoembolization procedure for treatment of hepatocellular carcinoma: a case report. J Gastrointest Cancer 2014; 45 Suppl 1: 195-197.

11. Egan M, Maglione PJ: Multiple reasonably tolerated percutaneous coronary interventions in a patient with iodide mumps. Ann Allergy Asthma Immunol 2015; 115: 253-254.
12. Ghosh RK, Somasundaram M, Ravakhah K: Iodide mumps following fistulogram in a haemodialysis patient. BMJ Case Rep 2016. DOI: 10.1136/bcr-2015-214037.

13. Elder $\mathrm{AM}, \mathrm{Ng} \mathrm{MK}$ : Iodide mumps complicating coronary and carotid angiography. Heart Lung Circ 2017; 26: e14-e15.

14. Afshar M, Alhussein M: Iodide-associated sialadenitis. N Engl J Med 2017; 376: 868 .

15. Zhang G, Li T, Wang H, Wang H, Liu J: The pathogenesis of iodide mumps - A case report. Medicine (Baltimore) 2017; 96: e8881.

16. Londrino F, Granata A, Tatangelo P, Boiceff S, Dessì G, Palumbo R: Iodide mumps following vascular access management. J Vasc Access 2018: 1129729818762009.

17. Gilgen-Anner Y, Heim M, Ledermann HP, Bircher AJ: Iodide mumps after contrast media imaging: a rare adverse effect to iodine. Ann Allergy Asthma Immunol 2007; 99: 93-98.

18. Waugh WH: Use of cortisone by mouth in prevention and therapy of severe iodism. AMA Arch Intern Med 1954; 93: 299-303.

19. Lang JH, Lasser EC, Talner LB, Lyon S, Coel M: Inorganic iodide in contrast media. Invest Radiol 1974; 9: 51-55. 